\title{
Allergies and risk of colorectal cancer: a systematic review and meta-analysis of observational studies
}

\author{
Jianrong Ye ${ }^{1,}{ }^{,}$, Ailaiti Talaitit ${ }^{1, *}$, Yan Ma ${ }^{1}$, Qin Zhang ${ }^{1}$, Long $\mathrm{Ma}^{1}$, Hong Zheng ${ }^{1}$ \\ ${ }^{1}$ Department of Anesthesiology, First Affiliated Hospital of Xinjiang Medical University, Urumqi, Xinjiang, China \\ *These authors contributed equally to this work
}

Correspondence to: Hong Zheng, email: hongzpro211@126.com

Keywords: allergy, colorectal cancer, observational study, meta-analysis

Received: October 11, $2016 \quad$ Accepted: December 13, 2016

Published: January 11, 2017

\section{ABSTRACT}

A history of allergy or allergic condition has been reported to be associated with reduced risk of some types of malignancies. However, the understanding of this association for colorectal cancer (CRC) is controversial. We conducted a meta-analysis of CRC risk in individuals who had history of allergy compared to those without the history of allergic condition. Pumbed and Embase databases were searched for relevant studies. The adjusted relative risk (RR) and $95 \%$ confidence interval (CI) were pooled using the random-effects model. Nine studies, including 775, 178 individuals, were eligible for inclusion. The pooled estimate showed no significant association between history of allergy and CRC risk (adjusted RR 1.01, $95 \%$ CI 0.88-1.17). Subgroup analyses confirmed the neutral association stratified by tumor location (colon: $n=6$ studies; adjusted RR 1.01, $95 \%$ CI 0.81-1.25; rectum: $n=6$ studies; adjusted RR 0.94, 95\% CI 0.77-1.15; colorectum: $n=3$ studies; adjusted RR 0.92, $95 \%$ CI 0.70 to 1.21), sex (male: $n=4$ studies; adjusted RR 0.93, $95 \%$ CI 0.81-1.07; female: $n=6$ studies; adjusted RR 0.94, $95 \%$ CI 0.80-1.09) or by allery type (asthma: $n=5$ studies; adjusted RR 1.16, $95 \%$ CI 0.96-1.42; hay fever: $n=4$ studies; adjusted RR 0.93, $95 \%$ CI 0.86-1.03). Meta-analysis of existing evidence provides a neutral association between allergies and CRC risk. Future well-designed prospective cohort studies should be conducted to better understand this association.

\section{INTRODUCTION}

Colorectal cancer (CRC) represents the third most common cancer and the fourth cause of cancer death worldwide, with an estimated 1.4 million new colorectal cancer cases and 693,900 deaths in 2012 globally [1]. Allergies, known as asthma, hay fever/allergic rhinitis and other allergy-related conditions have been reported to be linked with risk of various cancer types [2-8], indicating a potential preventive effect of allergic conditions against CRC [9-10]. Studies have suggested the potential protective effect of allergy on cancer development through activating IgE-mediated immune reactions for cancer cell, inducing the protective role of ACCs for various tumors, such as lung cancer and brain cancer $[2,8,11]$.

Accumulating evidence suggests a pivotal role of allergic conditions in modulation of immune function $[12,13]$. We have long recognized the important roles of host immunity and inflammation in regulating tumour evolution [14-18]. Local immunity of tumour microenvironment may obliterate cancerous cells, promoting or preventing their tumourigenic potential, thus determining the fate of emerging tumour. However, despite vast evidence for the role of allergic conditions in immunity and the role of immunity in tumour development, no consensus among studies has yet been reached whether there was association between allergies and CRC risk. The purpose of this study was to conduct a meta-analysis of CRC risk in individuals who had history of allergy compared to those without the history of allergic condition.

\section{RESULTS}

We performed this meta-analysis in accordance with the Preferred Reporting Items for Systematic reviews and Meta-Analyses (PRISMA) guidelines [19] (Supplementary Table S4). 


\section{Search and selection of studies}

We retrieved 3,220 unique citations in the initial literature search and 39 potentially relevant studies for full-text review. After removing 30 studies, a total of 9 cohort studies met our inclusion criteria and were involved in the meta-analysis [20-28] (Figure 1).

\section{Study characteristics}

The baseline characteristics of the identified studies are shown in Table 1. A total of 775,178 participants were included in this study with a median sample size of 77,952 (range, 3,308 to 199,112). The median follow-up period was 10.9 (range 8 to 18) years. All of the included studies were published between 1993 and 2015 in English peer-reviewed journals.

Eight of the nine studies involved multicentric data $[20-23,25-28]$, whereas only one was single center study [24]. Four studies were conducted in North America [20, 22, 24, 27], four in Europe [21, 23, $25,28]$ and one in Australia [26]. For study design, eight were population-based cohort study, whereas one was community-based cohort study. The included studies investigated allergies categorized as asthma, hay fever, atopy or other allergic related conditions. The exposure of allergy was ascertained mostly by self-administered questionnaires, while others through research or health care databases, social insurance institution register and hospital discharge register. The following covariates were frequently applied for the adjustment for statistical analyses: age, sex, smoking status, body mass index, alcohol intake and physical activity (Table 1).

\section{Study quality}

Supplementary Table S3 lists the quality scores of these studies based on the Newcastle-Ottawa scale. The methodological quality score were considered high in seven of nine cohort studies [21-23, 24-27], and moderate in four [20, 21, 23, 28]. Most studies had full scores for the representativeness of the exposed and non-exposed cohort, but some lacked scores for comparability on the basis of design or analysis having not controlled for possible confounders. Other studies lacked scores for inadequacy of follow-up.

\section{Allergies and risk of CRC}

Meta-analysis of all cohort studies showed that the history of allergy (as compared to no history of allergy was not associated with a statistically significant reduction in CRC incidence ( $n=9$ studies; adjusted RR $1.01,95 \%$ CI 0.88 to 1.17 ) (Figure 2). We selected a random-effects model when performing meta-analyse, and considerable heterogeneity was seen between studies (Cochran' s Q test $P<0.01, \mathrm{I}^{2}=88.3 \%$ ). Significant reduction in heterogeneity was seen when studies involved in colorectum, hay fever, USA/Canada region, sample size less than 1000, questionnaire based assessment method and quality score $>6$, indicating that the heterogeneity could be explained partly by these factors (Table 2 ).

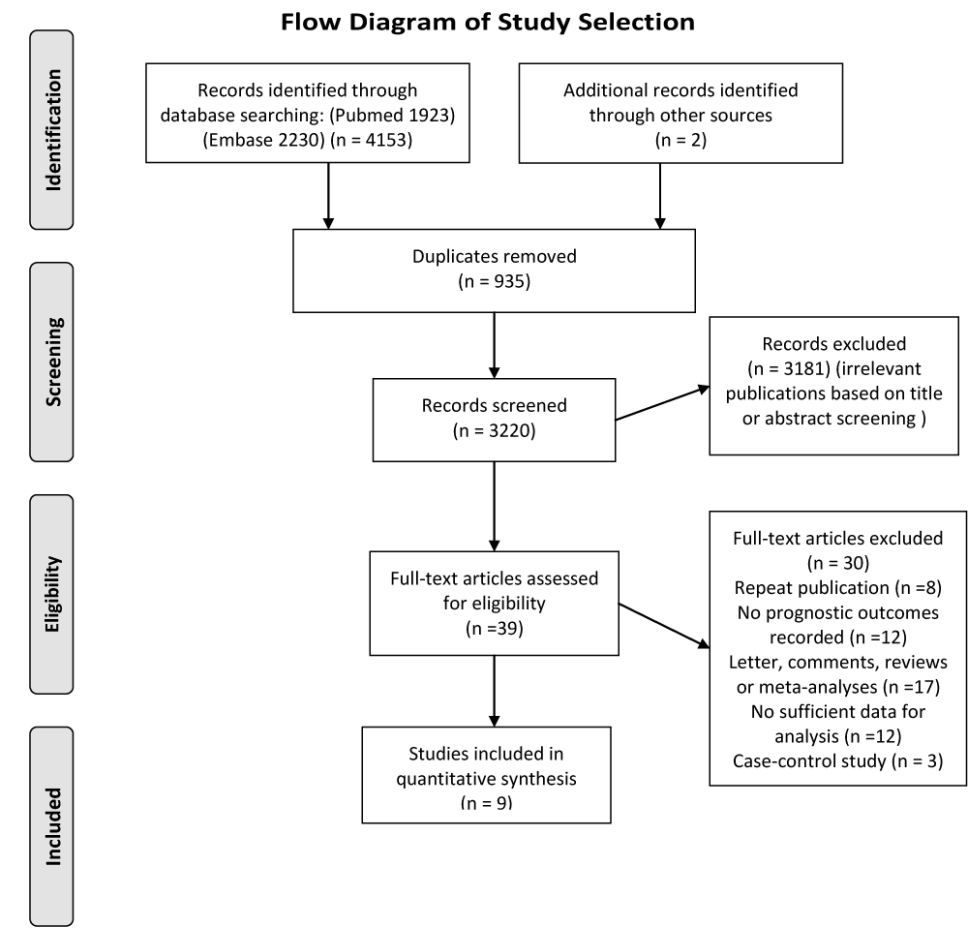

Figure 1: Flow diagram of the study selection. 
Table 1: Baseline characteristics of the included studies

\begin{tabular}{|c|c|c|c|c|c|c|c|c|c|c|c|c|c|c|c|}
\hline Study & Year & Region & $\begin{array}{c}\text { Inclusion } \\
\text { period }\end{array}$ & Study name & $\begin{array}{c}\text { Single or } \\
\text { multicenter }\end{array}$ & Study design & $\begin{array}{c}\text { Sample size } \\
\text { (Exposure } \\
\text { No.) } \\
\end{array}$ & $\begin{array}{c}\text { Mean or } \\
\text { median age } \\
(y s)\end{array}$ & Male Sex $(\%)$ & $\begin{array}{c}\text { Type of } \\
\text { allergic } \\
\text { conditions }\end{array}$ & $\begin{array}{c}\text { Exposure assessment } \\
\text { method }\end{array}$ & $\begin{array}{l}\text { Measure of } \\
\text { associations }\end{array}$ & $\begin{array}{c}\begin{array}{c}\text { Outcome } \\
\text { assessment } \\
\text { registry }\end{array} \\
\end{array}$ & $\begin{array}{l}\text { Years of } \\
\text { follow-up }\end{array}$ & Adjusted variables \\
\hline $\begin{array}{c}\text { Tambe } \\
\text { et al. }\end{array}$ & 2015 & USA & 1993-1996 & $\begin{array}{l}\text { Multiethnic } \\
\text { Cohort Study } \\
\text { of Diet and } \\
\text { Cancer }\end{array}$ & $\mathrm{M}$ & $\begin{array}{l}\text { Population based } \\
\text { prospective cohort } \\
\text { study }\end{array}$ & 199112 (51973) & $\begin{array}{c}\text { Mean (E/NE): } \\
59.38 / 60.81\end{array}$ & $89496(44.95)$ & $\begin{array}{c}\text { Asthma, hay } \\
\text { fever, or allergy }\end{array}$ & $\begin{array}{c}\text { A detailed, 26-page } \\
\text { self-administered } \\
\text { questiomnaire }\end{array}$ & RR & $\begin{array}{l}\text { Cohort linkage } \\
\text { with } \\
\text { the } \\
\text { Surveillance, } \\
\text { Epidemiology, } \\
\text { and End } \\
\text { Results (SEER) } \\
\text { registries }\end{array}$ & 17 & 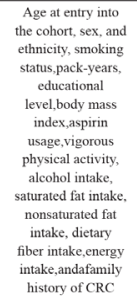 \\
\hline $\begin{array}{l}\text { Skaaby } \\
\text { et al. }\end{array}$ & 2014 & Denmark & $1976-2006$ & $\begin{array}{l}5 \text { Danish } \\
\text { studies } \\
\text { including } \\
\text { Monical, } \\
\text { Allergy98, } \\
\text { Inter99, } \\
\text { Health2006 } \\
\text { and } \\
\text { 1936-cohort. }\end{array}$ & M & $\begin{array}{l}\text { Population based } \\
\text { prospective cohort } \\
\text { study }\end{array}$ & 14849 (3994) & $\begin{array}{c}\text { Mean } \\
\text { Monical:45; } \\
\text { Allergy98: 40; } \\
\text { Inter99: 46.1; } \\
\text { Health2006: } \\
\text { 49.0; } \\
\text { 1936-cohort: } \\
\text { 40.4 }\end{array}$ & $\begin{array}{c}7155 \\
(48.18)\end{array}$ & Atopy & $\begin{array}{l}\text { Questionnaires, } \\
\text { physical examinations, } \\
\text { and } \\
\text { blood tests }\end{array}$ & HR & $\begin{array}{l}\text { Danish Cancer } \\
\text { Register }\end{array}$ & 11.8 & $\begin{array}{l}\text { Study,sex,education, } \\
\text { activity, smoking } \\
\text { habits, alcohol } \\
\text { intake, and BMI }\end{array}$ \\
\hline $\begin{array}{l}\text { Jacobs et } \\
\text { al. }\end{array}$ & 2013 & USA & 1992-1993 & $\begin{array}{l}\text { CPS-II } \\
\text { Nutrition } \\
\text { Cohort }\end{array}$ & M & $\begin{array}{l}\text { Population based } \\
\text { prospective } \\
\text { study } \\
\text { sthort }\end{array}$ & $174917(26238)$ & $>40$ & $26208(52.9)$ & $\begin{array}{l}\text { Asthma, hay } \\
\text { fever }\end{array}$ & $\begin{array}{l}\text { A mailed } \\
\text { administered } \\
\text { questionnaire }\end{array}$ & RR & $\begin{array}{l}\text { Medical } \\
\text { records, or } \\
\text { through linkage } \\
\text { with state cancer } \\
\text { registries; } \\
\text { linkage with } \\
\text { the National } \\
\text { Death Index }\end{array}$ & 10 & $\begin{array}{l}\text { Age, sex, race, } \\
\text { eductation, BMI, } \\
\text { physical activity. } \\
\text { smoking, aspirin } \\
\text { use, and history of } \\
\text { colorectal endoscopy }\end{array}$ \\
\hline Chat et al. & 2012 & USA & $1988-1994$ & $\begin{array}{l}\text { NHANES III } \\
\text { Female Cohort }\end{array}$ & M & $\begin{array}{l}\text { Population based } \\
\text { retrospective cohort } \\
\text { study }\end{array}$ & $4600(2331)$ & Mean 59.56 & 0 & $\begin{array}{l}\text { RC: symptoms } \\
\text { of allergic } \\
\text { rhinitis or } \\
\text { conjunctivitis } \\
\text { without } \\
\text { wheezing; WZ: } \\
\text { wheczing }\end{array}$ & $\begin{array}{l}\text { Self-administered } \\
\text { questionnaire }\end{array}$ & OR & 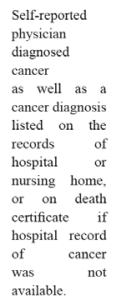 & NR & $\begin{array}{l}\text { Age, race, education, } \\
\text { income, asthma, } \\
\text { CopD, C-reacecive } \\
\text { protein, obesity, } \\
\text { smoking. } \\
\text { alacohol drinking, } \\
\text { physical inactivity, } \\
\begin{array}{l}\text { and menopausal } \\
\text { status. }\end{array}\end{array}$ \\
\hline $\begin{array}{l}\text { Prizment } \\
\text { et al. }\end{array}$ & 2007 & USA & $1997-2004$ & $\begin{array}{l}\text { Iowa Women's } \\
\text { Health Study }\end{array}$ & $\mathrm{s}$ & $\begin{array}{l}\text { Populationbased } \\
\text { prospective cohort } \\
\text { study }\end{array}$ & $21,292(6,765)$ & Mean 72.1 & 0 & $\begin{array}{l}\text { Asthma, hay } \\
\text { fever, eczema } \\
\text { or allergy of } \\
\text { the skin, or } \\
\text { other allergic } \\
\text { conditions }\end{array}$ & $\begin{array}{l}\text { Five self-administered } \\
\text { questionnaire }\end{array}$ & HR & $\begin{array}{l}\text { Annual linkage } \\
\text { to the State } \\
\text { Health Registry } \\
\text { of Iowa, part of } \\
\text { the Surveillance, } \\
\text { Epidemiology, } \\
\text { and End Results } \\
\text { Program. }\end{array}$ & 8 & $\begin{array}{l}\text { Age, pack-years, } \\
\text { total energy intake, } \\
\text { calcium, red meat, } \\
\text { and multivitamin } \\
\text { use in 1986. BMI in } \\
1997 \text {, and diabetes } \\
\text { and HRT use before } \\
1997\end{array}$ \\
\hline $\begin{array}{l}\text { Talbot- } \\
\text { Smith et al. }\end{array}$ & 2002 & Australia & 1981-1999 & $\begin{array}{l}\text { The } 1981 \\
\text { Busselton } \\
\text { Health Survey }\end{array}$ & M & $\begin{array}{l}\text { Community-based, } \\
\text { prospective study }\end{array}$ & $\begin{array}{l}3308 \\
(1343)\end{array}$ & $\begin{array}{l}\text { Mean male: } \\
50.7 ; \text { female: } \\
50\end{array}$ & $1522(46.01)$ & $\begin{array}{l}\text { Asthma, hay } \\
\text { fever, atopy }\end{array}$ & $\begin{array}{l}\text { A history of physician- } \\
\text { diagnosed based on a } \\
\text { questionnaires }\end{array}$ & HR & $\begin{array}{lr}\text { Linkage } & \text { to } \\
\text { the } & \text { West } \\
\text { Australian } \\
\text { Cancer Registry }\end{array}$ & 18 & $\begin{array}{l}\text { Age, smoking status, } \\
\text { and body mass index }\end{array}$ \\
\hline $\begin{array}{l}\text { Hemminki } \\
\text { et al. }\end{array}$ & 2014 & Germany(sweden) & $1964-2010$ & $\begin{array}{l}\text { Swedish } \\
\text { nationwide } \\
\begin{array}{ll}\text { health } \quad \text { care } \\
\text { cohort }\end{array}\end{array}$ & M & $\begin{array}{l}\text { Nationwide } \\
\text { populationbased } \\
\text { prospective cohort } \\
\text { study }\end{array}$ & 138723 & $\begin{array}{l}\text { Mean } \\
24\end{array}$ & $\begin{array}{l}70521 \\
(50.84)\end{array}$ & $\begin{array}{l}\text { Hay fever, } \\
\text { allergic rhinitis }\end{array}$ & $\begin{array}{l}\text { Three Swedish } \\
\text { health care } \\
\text { databases(Hospital } \\
\text { Discharge } \\
\text { Register,Outpatient } \\
\text { Registry,Primary } \\
\text { Health } \\
\text { Registry) Care }\end{array}$ & SIR & $\begin{array}{l}\text { Swedish Cancer } \\
\text { Registry }\end{array}$ & 8 & None \\
\hline $\begin{array}{l}\text { Vesterinen } \\
\text { et al. }\end{array}$ & 1993 & Finland & $1970-1985$ & $\begin{array}{l}\text { FTnland } \\
\text { nationwide } \\
\text { cohort } \\
\text { study }\end{array}$ & M & $\begin{array}{l}\text { Nationwide } \\
\text { populationbased } \\
\text { prospective cohort } \\
\text { study }\end{array}$ & 77952 & $35-84$ & $\begin{array}{l}35126 \\
(45.06)\end{array}$ & Asthma & $\begin{array}{l}\text { Nationwide Social } \\
\text { Insurance Institution } \\
\text { register }\end{array}$ & SIR & $\begin{array}{l}\text { Finnish Cancer } \\
\text { Registry }\end{array}$ & & None \\
\hline Ji et al. & 2009 & Swedish & 1965-2004 & $\begin{array}{l}\text { Swedish } \\
\text { Hospital } \\
\text { Discharge } \\
\text { Register cohort }\end{array}$ & M & $\begin{array}{l}\text { Nationwide } \\
\text { populationbased } \\
\text { prospective cohort } \\
\text { study }\end{array}$ & 140425 & NR & NR & Asthma & $\begin{array}{l}\text { Swedish Hospital } \\
\text { Discharge Register }\end{array}$ & SIR & $\begin{array}{l}\text { National } \\
\text { Swedish Cancer } \\
\text { Registry }\end{array}$ & $1-14$ & None \\
\hline
\end{tabular}

Abbreviations: BMI, body mass index; CI, confidence interval; E, exposure; het, heterogeneity; HR, hazard ratio; M, multicenter; NA, not available; NE, non-exposure; OR, odd ratio; S, single center; SIR, standardized incidence ratio;

\section{Sensitivity analysis and publication bias}

Sensitivity analysis suggested that exclusion of any one of the studies in turn did not alter the trend of the summary estimate. Further subgroup analysis stratified by some baseline characteristics showed that the association almost remained constant across the subgroups (Table 2).

Visual impression of the funnel plot revealed some asymmetry. However, the Egger' s regression asymmetry test $(P=0.42)$ suggested no publication bias. The results of the trim-and-fill method indicated that three studies might have been missing and the adjusted pooled RR was 0.93 (95\% CI 0.79 to 1.09 ) when inputing these three hypothised studies (Figure 3), which was consistent with the main results.

\section{DISCUSSION}

\section{Principle findings}

In this meta-analysis involving 9 cohort studies analyzing the effect of allergies on modifying the risk of CRC in more than 775,000 individuals, we found that history of allergy was not associated with a decreased risk of CRC. This neutral association was independent of gender, tumor location, research region, allergy 
Table 2: Subgroup analyses according to some baseline characteristics

\begin{tabular}{|c|c|c|c|c|c|}
\hline Variables & $\mathbf{R R}$ & $95 \% \mathrm{CI}$ & Heterogeneity (\%) & $\begin{array}{l}P \text { for subgroup } \\
\text { difference }\end{array}$ & $\begin{array}{l}\text { No. of included } \\
\text { Studies }\end{array}$ \\
\hline Total & 1.01 & 0.88 to 1.17 & 88.3 & - & 9 \\
\hline $\begin{array}{l}\text { Tumor location } \\
\text { Colon } \\
\text { Rectum } \\
\text { Colorectum }\end{array}$ & $\begin{array}{l}1.01 \\
0.94 \\
0.92\end{array}$ & $\begin{array}{l}0.81 \text { to } 1.25 \\
0.77 \text { to } 1.15 \\
0.70 \text { to } 1.21\end{array}$ & $\begin{array}{c}92.4 \% \\
83.8 \% \\
0\end{array}$ & 0.855 & $\begin{array}{l}6 \\
6 \\
3\end{array}$ \\
\hline $\begin{array}{l}\text { Sex } \\
\text { Male } \\
\text { Female }\end{array}$ & $\begin{array}{l}0.93 \\
0.94\end{array}$ & $\begin{array}{l}0.81 \text { to } 1.07 \\
0.80 \text { to } 1.09\end{array}$ & $\begin{array}{l}65.1 \\
65.8\end{array}$ & 0.938 & $\begin{array}{l}4 \\
6\end{array}$ \\
\hline $\begin{array}{l}\text { Allergy type } \\
\text { Asthma } \\
\text { Hay fever }\end{array}$ & $\begin{array}{l}1.16 \\
0.95\end{array}$ & $\begin{array}{l}0.96 \text { to } 1.42 \\
0.85 \text { to } 1.06\end{array}$ & $\begin{array}{c}77.5 \\
0\end{array}$ & 0.006 & $\begin{array}{l}5 \\
4\end{array}$ \\
\hline $\begin{array}{l}\text { Research region } \\
\text { USA/Canada } \\
\text { Europe }\end{array}$ & $\begin{array}{l}0.89 \\
1.04\end{array}$ & $\begin{array}{l}0.84 \text { to } 0.93 \\
0.86 \text { to } 1.27\end{array}$ & $\begin{array}{c}1.3 \\
88.5\end{array}$ & 0.112 & $\begin{array}{l}3 \\
6\end{array}$ \\
\hline $\begin{array}{l}\text { Research center } \\
\text { Single } \\
\text { Multicenter }\end{array}$ & $\begin{array}{l}0.74 \\
1.05\end{array}$ & $\begin{array}{l}0.62 \text { to } 0.88 \\
0.90 \text { to } 1.22\end{array}$ & 88.2 & 0.003 & $\begin{array}{l}1 \\
8\end{array}$ \\
\hline $\begin{array}{l}\text { Sample size } \\
\quad \geq 10000 \\
\quad<10000\end{array}$ & $\begin{array}{l}1.02 \\
0.92\end{array}$ & $\begin{array}{l}0.88 \text { to } 1.18 \\
0.58 \text { to } 1.46\end{array}$ & $\begin{array}{c}91.2 \\
0\end{array}$ & 0.686 & $\begin{array}{l}7 \\
2\end{array}$ \\
\hline $\begin{array}{l}\text { Exposure assessment } \\
\text { method }\end{array}$ & & & & 0.069 & \\
\hline $\begin{array}{l}\text { Questionnaire based } \\
\text { Health care-based } \\
\text { registry }\end{array}$ & $\begin{array}{l}0.89 \\
1.13\end{array}$ & $\begin{array}{l}0.81 \text { to } 1.01 \\
0.89 \text { to } 1.42\end{array}$ & $\begin{array}{l}41.2 \\
90.8\end{array}$ & & $\begin{array}{l}6 \\
3\end{array}$ \\
\hline $\begin{array}{l}\text { Adequate baseline } \\
\text { characteristics adjusted }\end{array}$ & & & & 0.069 & \\
\hline Yes & 0.89 & 0.81 to 1.01 & 41.2 & & 6 \\
\hline No & 1.13 & 0.89 to 1.42 & 90.8 & & 3 \\
\hline $\begin{array}{l}\text { Study quality } \\
\text { Quality score }>6 \\
\text { Quality score } \leq 6\end{array}$ & $\begin{array}{l}0.95 \\
1.15\end{array}$ & $\begin{array}{l}0.84 \text { to } 1.05 \\
0.80 \text { to } 1.49\end{array}$ & $\begin{array}{l}58.9 \\
95.0\end{array}$ & 0.272 & $\begin{array}{l}7 \\
2\end{array}$ \\
\hline
\end{tabular}

Abbreviations: CI, confidence interval; RR, relative risk.

exposure assessment method, allergy type, sample size, study quality, or allergy type. Sensitivity analysis and the trim-and-fill method confirmed the main findings.

\section{Strengths of the study}

To the best of our knowledge, this is the first metaanalysis investigating the association between history of allergy and risk of CRC exclusively with the largest sample size till now. The strengths of our study include a contemporaneous and exhaustive search of the major global electronic databases using a comprehensive search strategy, which allow us identify sufficient studies and summary the data from over 775,000 recruited individuals, thus objectively assess the association between ACCs and risk of CRC. Additionally, though limited number of studies were involved in some of the subgroup analyses, most of the studies were large-scale cohorts with a median sample size of 77,952 (range, 3,308 to 199,112) and large sample size implied high statistical power. Second, the literature search, eligibility assessment, data extraction, and quality assessment were conducted independently by at least two investigators and one senior author. Third, in order to more conservatively calculate the risk estimate of $\mathrm{CRC}$, we used a random effects model to combine data in overall population and subgroup analyses were 
thoroughly undertaken according to gender, tumor location, type of allergy and other baseline characteristics. Fourth, almost all of the studies selected were limited to those with population-based registries with representative samples, which provided better evidence than those provided by data derived from convenience samples. Finally, we assessed for publication bias using different approaches (funnel plot, Egger's test as well as trim and filled method), giving sufficient evidence to confirm the evidence based on the current available studies.

\section{Limitations of the study}

Several limitations should be addressed. First, as a meta-analysis of observational studies, there was a lack of the experimental random allocation of the intervention like randomized controlled trials which was an optimal method to test exposure - outcome hypotheses. Second, the adjusted variables varied among studies. They generally failed to adjust these following important risk factors for CRC in all studies: family history of CRC or other tumors, diet habits, smoking, alcohol use, nonsteroidal antiinflammatory drugs (NSAID) use and other related factors, which could be some of the influential factors of CRC. Moreover, three studies used SIRs to estimate CRC risk [21, 23, 28]. SIRs, known to inherently correspond to RR estimates and obtained only through adjustment for age and calendar time [29], would likely to overestimate cancer risk $[30,31]$. Third, the summary RR must be interpreted with caution as the ascertainment of allery exposure varied among included studies. Most of the studies involve self-administered questionnaire

\begin{tabular}{|c|c|c|c|c|}
\hline Study & Risk Ratio & $\mathbf{R} \mathbf{R}$ & \multicolumn{2}{|c|}{$95 \%-\mathrm{Cl} \mathbf{W}$ (random) } \\
\hline Tambe NA et al 2015 & & 0.86 & {$[0.81 ; 0.91]$} & $11.0 \%$ \\
\hline Skaaby T et al 2014 & $\frac{1}{4}$ & 0.92 & {$[0.65 ; 1.29]$} & $6.8 \%$ \\
\hline Hemminki K et al 2014(colon) & & 0.87 & {$[0.75 ; 1.01]$} & $10.0 \%$ \\
\hline Hemminki K et al 2014(rectum) & & 0.89 & {$[0.72 ; 1.10]$} & $9.0 \%$ \\
\hline Jacobs EJ et al 2013 & & 0.94 & {$[0.86 ; 1.03]$} & $10.8 \%$ \\
\hline Chae YK et al 2012(RC) & & 1.24 & {$[0.33 ; 4.69]$} & $1.0 \%$ \\
\hline Chae YK et al 2012(WZ) & & 1.92 & {$[0.06 ; 61.08]$} & $0.2 \%$ \\
\hline Ji J et al 2009(colon) & + & 1.57 & {$[1.39 ; 1.78]$} & $10.3 \%$ \\
\hline Ji J et al 2009(rectum) & + & 1.24 & {$[1.07 ; 1.44]$} & $10.0 \%$ \\
\hline Prizment AE et al 2007 & + & 0.74 & {$[0.62 ; 0.88]$} & $9.6 \%$ \\
\hline Talbot-Smith A et al 2002 & $\frac{1}{1}$ & 0.87 & {$[0.53 ; 1.43]$} & $4.7 \%$ \\
\hline Vesterinen E et al 1993(colon) & + & 1.17 & {$[0.97 ; 1.41]$} & $9.4 \%$ \\
\hline Vesterinen E et al 1993(rectum) & + & 1.26 & {$[0.92 ; 1.73]$} & $7.2 \%$ \\
\hline Random effects model & $\beta$ & 1.01 & {$[0.88 ; 1.17]$} & $100 \%$ \\
\hline \multicolumn{5}{|l|}{ Heterogeneity: I-squared $=88.3 \%, p<0.0001$} \\
\hline & & & & \\
\hline 0.05 & 0.512 & 0 & & \\
\hline
\end{tabular}

Figure 2: Association between history of allergy and risk of colorectal cancer.

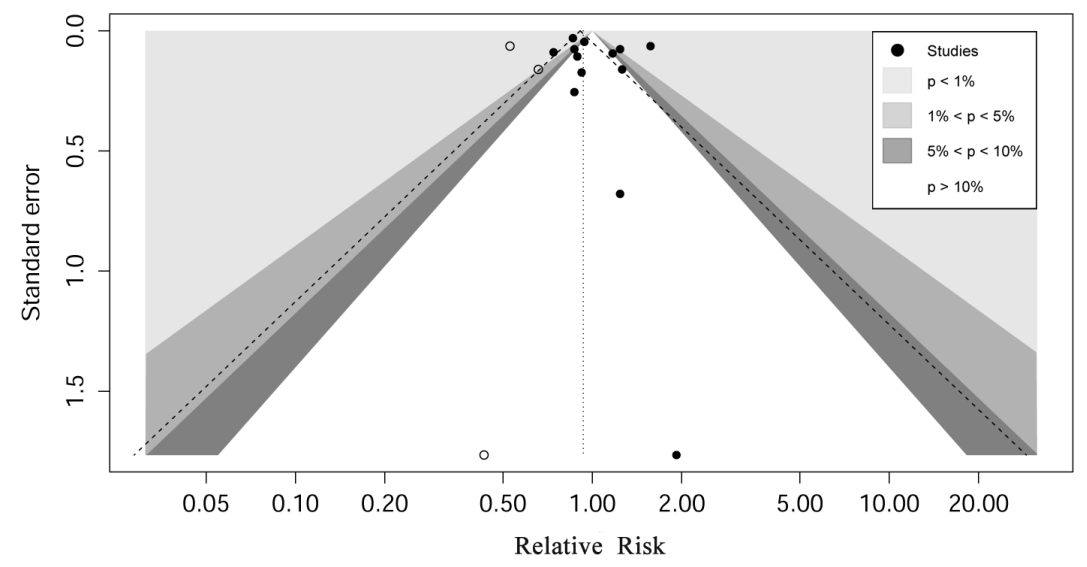

Figure 3: Contour enhanced funnel plot for meta-analysis of the association between history of allergy and risk of colorectal cancer. 
to report allergic conditions and symptoms, while some used hospital discharge register. Considerable inter-study heterogeneity did exist but we made an attempt to account for this variation by conducting subgroup analyses and some of the examined variables were really attributed to the significant heterogeneity (Table 2). In addition, as the included studies were all study-level studies, we could not abstract more detailed information of each individual, thus some of the subgroup analyses we were interested in could not be performed. For example, for some specific allergy types, though we have investigated asthma and hay fever subtype, limited number of studies in each subtype resulted in insufficient statistical power to draw definite conclusions for the true associations. Another major limitation was that the assessment method of exposure was mostly through self-administered questionnaires rather than the objective laboratory measurement of allergy. So we propose that more well designed large-scale cohort studies investigating the association between allergies and $\mathrm{CRC}$ risk should be aunched. Furthermore, funnel plot asymmetry indicated the overestimation of the effect size. However, the adjusted RR by using trim and filled method did not largely alter the statistical significance of the results, indicating the robustness of our findings. Finally, we did not include the unpublished studies. Since the omission the unpublished studies will lead to asymmetry of the funnel plot, the combined effect from meta-analysis will overestimate the effect of exposure. Such asymmetry might also result from the overestimation of the effects of exposure in smaller studies of lower methodological quality [32].

The mechanisms of tumorigenesis associated with allery are controversial. There have been two contradictory theories proposed. One theory was that cancer risk could be reduced by some allergic conditions through immune surveillance, inducing immune reactions to remove malignant tumor cells, whereas the other theory proposes that allergic conditions can result in continuous tissue inflammation, damage and repair, which increases the risk of cancer $[33,34]$. A meta-analysis by Olson et al. supported the former theory in pancreatic cancer that allergic conditions could be a protective factor for specific cancer risk. However, they only found the reduced risk for hay fever and allergy to animals, but not for asthma or other allergies [35]. Our study finds that neither hay fever nor asthma has a protective association. Perhaps some larger population-based prospective cohort studies can give further evidence for this association and provide directions for future research on this topic.

In summary, this systematic review and meta-analysis provide evidence that do not support a substantial a protective or harmful association between history of allergy and risk of CRC. Future well-designed prospective cohort studies should be conducted to better understand this association. Furthermore, studies should include analysis on more types of allergy in order to investigate if the effect of specific type of allergy on the tumorigenesis of CRC.

\section{MATERIALS AND METHODS}

\section{Search strategy}

A systematic search of literature was performed on January 26, 2016, in PubMed and Embase from the initial available date according to the Cochrane review guidelines. We used the following sets of Mesh/Emtree terms for searching: allergy, asthma, allergens and allergic rhinitis; colorectal neoplasms, colonic neoplasms and rectal neoplasms. The detailed search strategies are presented in Supplementary Tables S1-S2. Besides, we also conducted manual search of the reference lists of related reviews or meta-analyses identified through the above systematic database searches. We also searched the titles of published papers in the following major surgeryrelated journals for the period of last 10 years: Annals of Surgery, British Journal of Surgery, JAMA Surgery, Annals of Surgical Oncology, Surgery, and American Journal of Surgery. However, we did not include 'grey' or unpublished literature in our meta-analysis.

\section{Eligibility criteria}

Allergies or allergic conditions were defined as a self-report history of having been previously diagnosed by a physician that the respondent had asthma, hay fever, skin or food allergy, or any other allergy. All abstracts examining risk estimates of the association between history of allergy and CRC were screened for full-text review. Studies were considered eligible for inclusion if they satisfied the following criteria: prospective or retrospecitve human cohort studies; studies investigating the association between history of allergy and CRC and reporting the corresponding RRs or SIRs of CRC or sufficient data to calculate them.

\section{Data extraction and study quality assessment}

Two reviewers (J.Y. and A.T.) independently evaluated each eligible study and extract related data. Disagreements were resolved by discussion or by a third reviewer (H.Z.). A predesigned standardized data collection form regarding the baseline characteristics including the following items was used: first author, publication year, research country, inclusion period, study name, center involved, study design, sample size, mean/ median age of included individuals, percent of male individual, type of allergy, exposure assessment method, measure of associations, outcome assessment, years of follow-up and adjusted variables.

We used the Newcastle-Ottawa Scale (NOS) [36] to assess study quality, which was developed to give a full 
assessment of the methodological quality of observational studies. Eight items totally 9 points across three major scales are judged including selection of the participants, comparability of the participants and outcomes. Two reviewers (Q.Z, L.M) scored each study and each study receives an overall score for methodological quality, with a score of $>6$ (totally 9 ) indicating low risk of bias and a score of $\leq 6$ suggesting high risk of bias.

\section{Statistical analyses}

The meta-analysis was performed abided by the preferred reporting items for systematic reviews and meta-analyses (PRISMA) statement [37]. All statistical analyses were conducted using Stata software (StataCorp. 2013; Stata Statistical Software: Release 13, College Station, TX: StataCorp LP).

We extracted the adjusted relative risks (RRs), odd ratios (ORs), hazard ratios (HRs), standardized incidence ratios (SIRs) and corresponding 95\% confidence intervals (CIs), if available, from the included studies which were used to assess the association between history of allergy and $\mathrm{CRC}$ risk. For the low absolute risk of $\mathrm{CRC}$, it is expected that the four measures of association can yield similar estimates of RR. Therefore, we can reasonably consider that the pooling of RR estimates can ensure the comprehensiveness of the meta-analysis and maximization of the statistical power [38, 39].

Random-effects models were used to evaluate the pooled RR for the association between history of allergy and CRC incidence [40] because results from the random-effects model could more conservatively presented the true underlying effect among the included studies with varied backgroud. Between-study heterogeneity was evaluated by the chi-square test and $\mathrm{I}^{2}$ statistic [41]. An $\mathrm{I}^{2}>50 \%$ was considered significant heterogeneity.

Potential publication bias was evaluated through visual inspection of funnel plots combined with the Egger's regression test [42] served as statistical assessment of publication bias. We also conducted the Duval and Tweedie nonparametric "trim and fill" approach to further assess the impact of publication bias on the combined estimate [43]. Subgroup analysis was also performed according to some of the baseline characteristics regarding population features (sex, tumor site and research region), exposure (allergy exposure assessment method and allergy type), study design (research center and sample size) and other related factors which some of the heterogeneity may potentially attribute to. All statistical tests were two-sided, and significance was defined as a $P$ value less than 0.05 .

\section{Abbreviations}

Colorectal cancer (CRC); relative risk (RR); Confidence interval (CI); Newcastle-Ottawa Scale
(NOS); Preferred reporting items for systematic reviews and meta-analyses (PRISMA); Odd ratios (ORs); Hazard ratios (HRs); Standardized incidence ratios (SIRs).

\section{ACKNOWLEDGMENTS}

This project is supported by National Natural Science Foundation of China grant (81660522).

\section{CONFLICTS OF INTEREST}

The authors declare no competing financial interests.

\section{Authors' contributions}

J.Y. and H.Z. were responsible for the study design. J.Y and A.T. drafted and implemented the protocol under the guidance of H.Z.. J.Y., A.T., Q.Z. and L.M. screened the studies and extracted data. J.Y., A.T.and Q.Z. analyzed the data and provided statistical guidance. J.Y. and H.Z. drafted the manuscript. J.Y., A.T., Q.Z., L.M. and H.Z. contributed to the interpretation of results and subsequent revisions. The final version of the manuscript was approved by all of the authors. H.Z. are guarantors.

\section{REFERENCES}

1. Ferlay J, Soerjomataram I, Ervik M. (2015). GLOBOCAN 2012 v1. 0, Cancer Incidence and Mortality Worldwide: IARC CancerBase No. 11 [Internet]. Lyon, France. 2012.

2. Brenner AV, Linet MS, Fine HA, Shapiro WR, Selker RG, Black PM, Inskip PD. History of allergies and autoimmune diseases and risk of brain tumors in adults. International journal of cancer. 2002; 99:252-259.

3. Holly EA, Eberle CA, Bracci PM. Prior history of allergies and pancreatic cancer in the San Francisco Bay area. Am J Epidemiol. 2003; 158:432-441.

4. McWhorter WP. Allergy and risk of cancer. A prospective study using NHANESI followup data. Cancer. 1988; 62:451-455.

5. Schwartzbaum J, Jonsson F, Ahlbom A, Preston - Martin S, Lönn S, Söderberg KC, Feychting M. Cohort studies of association between self - reported allergic conditions, immune - related diagnoses and glioma and meningioma risk. Int J Cancer. 2003; 106:423-428.

6. Söderberg KC, Hagmar L, Schwartzbaum J, Feychting M. Allergic conditions and risk of hematological malignancies in adults: a cohort study. BMC Public Health. 2004; 4:1.

7. Turner MC, Chen Y, Krewski D, Ghadirian P. An overview of the association between allergy and cancer. Int J Cancer. 2006; 118:3124-3132.

8. Wigertz A, Lönn S, Schwartzbaum J, Hall P, Auvinen A, Christensen HC, Johansen C, Klæboe L, Salminen T, Schoemaker MJ. Allergic conditions and brain tumor risk. Am J Epidemiol. 2007; 166:941-950. 
9. Negri E, Bosetti C, La Vecchia C, Levi F, Tomei F, Franceschi S. Allergy and other selected diseases and risk of colorectal cancer. Eur J Cancer, 1999; 35:1838-41.

10. La Vecchia C, D'Avanzo B, Negri E, Franceschi S. History of selected diseases and the risk of colorectal cancer. Eur J Cancer, 1991; 27:582-6.

11. Castaing M, Youngson J, Zaridze D, SzeszeniaDabrowska N, Rudnai P, Lissowska J, Fabiánová E, Mates D, Bencko V, Foretova L. Is the risk of lung cancer reduced among eczema patients? Am J Epidemiol. 2005; 162:542-547.

12. Johansson S, Bieber T, Dahl R, Friedmann PS, Lanier BQ, Lockey RF, Motala C, Martell JAO, Platts-Mills TA, Ring J. Revised nomenclature for allergy for global use: Report of the Nomenclature Review Committee of the World Allergy Organization, October 2003. J Allergy Clin Imm. 2004; 113:832-836.

13. Jensen - Jarolim E, Achatz G, Turner M, Karagiannis S, Legrand F, Capron M, Penichet M, Rodriguez J, Siccardi A, Vangelista L. AllergoOncology: the role of $\operatorname{IgE}$ - mediated allergy in cancer. Allergy. 2008; 63:1255-1266.

14. Fridman WH, Pagès F, Sautès-Fridman C, Galon J. The immune contexture in human tumours: impact on clinical outcome. Nat Rev Cancer. 2012; 12:298-306.

15. Xia D, Wang D, Kim S-H, Katoh H, DuBois RN. Prostaglandin E2 promotes intestinal tumor growth via DNA methylation. Nat Med. 2012; 18:224-226.

16. Marzbani E, Inatsuka C, Lu H, Disis ML. The invisible arm of immunity in common cancer chemoprevention agents. Cancer Prev Res. 2013; 6:764-773.

17. Galon J, Mlecnik B, Bindea G, Angell HK, Berger A, Lagorce C, Lugli A, Zlobec I, Hartmann A, Bifulco C. Towards the introduction of the 'Immunoscore'in the classification of malignant tumours. J Pathol. 2014; 232:199-209.

18. Di Caro G, Marchesi F, Laghi L, Grizzi F. Immune cells: plastic players along colorectal cancer progression. J Cell Mol Med. 2013; 17:1088-1095.

19. Moher D, Liberati A, Tetzlaff J, Altman DG. PRISMA Group. Preferred reporting items for systematic reviews and meta-analyses: the PRISMA statement. Ann Intern Med, 2009; 151:264-9.

20. Chae YK, Neagu S, Kim J, Smyrlis A, Gooptu M, Tester W. Association between Common Allergic Symptoms and Cancer in the NHANES III Female Cohort. PLoS ONE. 2012; 7 .

21. Hemminki K, Försti A, Fallah M, Sundquist J, Sundquist K, Ji J. Risk of cancer in patients with medically diagnosed hay fever or allergic rhinitis. Int J Cancer. 2014; 135:2397-2403.

22. Jacobs EJ, Gapstur SM, Newton CC, Turner MC, Campbell PT. Hay Fever and asthma as markers of atopic immune response and risk of colorectal cancer in three large cohort studies. Cancer Epidem Biomar. 2013; 22:661-669.

23. Ji J, Shu X, Li X, Sundquist K, Sundquist J, Hemminki K. Cancer risk in hospitalised asthma patients. Brit J Cancer. 2009; 100:829-833.
24. Prizment AE, Folsom AR, Cerhan JR, Flood A, Ross JA, Anderson KE. History of allergy and reduced incidence of colorectal cancer, Iowa Women's Health Study. Cancer Epidem Biomar. 2007; 16:2357-2362.

25. Skaaby T, Nystrup Husemoen LL, Roswall N, Thuesen BH, Linneberg A. Atopy and development of cancer: a population-based prospective study. J Aller Cl Imm-Pract. 2014; 2:779-785.

26. Talbot-Smith A, Fritschi L, Divitini ML, Mallon DF, Knuiman MW. Allergy, atopy, and cancer: a prospective study of the 1981 Busselton cohort. Am J Epidemiol. 2003; 157:606-612.

27. Tambe NA, Wilkens LR, Wan P, Stram DO, Gilliland F, Park SL, Cozen W, Martinez-Maza O, Le Marchand L, Henderson BE, Haiman CA. Atopic allergic conditions and colorectal cancer risk in the Multiethnic Cohort Study. Am J Epidemiol. 2015; 181:889-897.

28. Vesterinen E, Pukkala E, Timonen T, Aromaa A. Cancer incidence among 78,000 asthmatic patients. Int J Epidemiol. 1993; 22:976-982.

29. Jensen A, Sharif H, Olsen JH, Kjær SK. Risk of breast cancer and gynecologic cancers in a large population of nearly 50,000 infertile Danish women. Am J Epidemiol. 2008; 168:49-57.

30. Klip H, Burger CW, Kenemans P and van Leeuwen FE. Cancer risk associated with subfertility and ovulation induction: a review. Cancer Causes Control. 2000; 11:319-344.

31. Mahdavi A, Pejovic T, Nezhat F. Induction of ovulation and ovarian cancer: a critical review of the literature. Fertil Steril. 2006; 85:819-826.

32. Sterne JAC, Gavaghan D, Egger M. Publication and related bias in meta-analysis: power of statistical tests and prevalence in the literature. J Clin Epidemiol. 2000; 53:1119-29.

33. Wang H, Rothenbacher D, Löw M, Stegmaier C, Brenner H, Diepgen TL. Atopic diseases, immunoglobulin E and risk of cancer of the prostate, breast, lung and colorectum. Int $\mathrm{J}$ Cancer. 2006; 119:695-701.

34. Talbot-Smith A, Fritschi L, Divitini ML, Mallon DF, Knuiman MW. Allergy, atopy, and cancer: a prospective study of the 1981 Busselton cohort. Am J Epidemiol. 2003; 157:606-612.

35. Olson SH, Hsu M, Satagopan JM, Maisonneuve P, Silverman DT, Lucenteforte E, Anderson KE, Borgida A, Bracci PM, Bueno-de-Mesquita HB. Allergies and risk of pancreatic cancer: a pooled analysis from the Pancreatic Cancer Case-Control Consortium. Am J Epidemiol. 2013:kwt052.

36. Wells G, Shea B, O'connell D, Peterson J, Welch V, Losos M, Tugwell P. (2015). The Newcastle-Ottawa Scale (NOS) for assessing the quality of nonrandomised studies in meta-analyses. Ottawa Hospital Research Institute; 2011. oxford. asp). 
37. Liberati A, Altman DG, Tetzlaff J, Mulrow C, Gøtzsche PC, Ioannidis JP, Clarke M, Devereaux PJ, Kleijnen J, Moher D. The PRISMA statement for reporting systematic reviews and meta-analyses of studies that evaluate health care interventions: explanation and elaboration. Ann Intern Med. 2009; 151:W-65-W-94.

38. Larsson SC, Mantzoros CS, Wolk A. Diabetes mellitus and risk of breast cancer: a meta-analysis. Int J Cancer, 2007, 121:856-62.

39. Adami HO. Textbook of cancer epidemiology. Oxford University Press, USA. 2008.
40. DerSimonian R, Laird N. Meta-analysis in clinical trials. Controlled clinical trials. 1986; 7:177-188.

41. Higgins JP, Thompson SG, Deeks JJ, Altman DG. Measuring inconsistency in meta-analyses. Bmj. 2003; 327:557-560.

42. Egger M, Smith GD, Schneider M, Minder C. Bias in metaanalysis detected by a simple, graphical test. Bmj. 1997; 315:629-634.

43. Duval S, Tweedie R. Trim and fill: a simple funnel-plotbased method of testing and adjusting for publication bias in meta-analysis. Biometrics. 2000; 56:455-463. 